\title{
Marcel Proust, La Fugitive. À la recherche du temps perdu
}

\section{Ludovico Monaci}

\section{(2) OpenEdition \\ 1 Journals}

\section{Édition électronique}

URL : https://journals.openedition.org/studifrancesi/21602

DOI : 10.4000/studifrancesi.21602

ISSN : 2421-5856

Éditeur

Rosenberg \& Sellier

\section{Édition imprimée}

Date de publication : 1 décembre 2019

Pagination : 601

ISSN : 0039-2944

\section{Référence électronique}

Ludovico Monaci, « Marcel Proust, La Fugitive. À la recherche du temps perdu », Studi Francesi [En ligne], 189 (LXIII | III) | 2019, mis en ligne le 01 mars 2020, consulté le 11 novembre 2021. URL : http:// journals.openedition.org/studifrancesi/21602 ; DOI : https://doi.org/10.4000/studifrancesi.21602

Ce document a été généré automatiquement le 11 novembre 2021.

\section{(c) (i) (9)}

Studi Francesi è distribuita con Licenza Creative Commons Attribuzione - Non commerciale - Non opere derivate 4.0 Internazionale. 


\title{
Marcel Proust, La Fugitive. À la recherche du temps perdu
}

\author{
Ludovico Monaci
}

\section{RÉFÉRENCE}

Marcel Proust, La Fugitive. À la recherche du temps perdu, VI - CEuvres complètes, 6, édition établie par L. Fraisse, Paris, Classiques Garnier, 2017, «Bibliothèque de littérature du xx siècle» 20, 1159 pp.

1 Classiques Garnier publie le sixième volume d'À la recherche du temps perdu: fruit du travail de longue haleine de l'éditeur Luc Fraisse, l'ouvrage se distingue, plus encore que par sa monumentalité, par la rigueur de l'approche et par la finesse et la complétude de l'analyse textuelle.

2 Le nœud central de l'«Introduction» (pp. 7-293) porte essentiellement sur la justification du choix éditorial de privilégier la version dite "longue" et, par conséquent, de restaurer le titre La Fugitive au détriment d'Albertine disparue (pp. 38-81). Une série de questions littéraires, biographiques, historiques, philosophiques et esthétiques sont avancées dans cette section et sont largement développées dans le corpus final des «Notes» (pp. 683-1105), au fur et à mesure que l'on se heurte à un point crucial du texte.

3 En parallèle, ce qui sort du lot de la mise en page du texte (pp. 301-681), pour lequel a été rétablie la ponctuation originelle, est la large portion consacrée à l'apparat critique. En fait, en essayant de repérer dans les cahiers de brouillons toutes les traces qui auraient $\mathrm{pu}$ fonder les situations romanesques de La Fugitive, l'éditeur transmet, «phrase par phrase et mot à mot» (p. 9) toutes les vicissitudes génétiques (ajouts, ratures, variantes, remaniements, etc.) des cahiers de mise au net et des deux dactylographies (l'une originale et l'autre de double), sans négliger les moindres détails des placards (dans les marges desquels figure le singulier «dialogue rédactionnel» 
entretenu par le frère de l'écrivain et Jean Paulhan, l'un des hommes les plus en vue de la NRF).

4 Sa nature systématique et claire fait de cette édition un outil incontournable pour se frayer un chemin dans le difficile décodage des volumes posthumes de la Recherche de Marcel Proust. 